\author{
NiCOLA SZEJA \\ Oddział Kliniczny Hematologii i Profilaktyki Chorób Nowotworowych w Chorzowie \\ Wydział Zdrowia Publicznego w Bytomiu \\ Ślaski Uniwersytet Medyczny w Katowicach \\ Piekarska 18, 41-900 Bytom \\ E-mail: nicola.szeja@med.sum.edu.pl
}

\title{
ENTOMOFAGIA - ASPEKTY ŻYWIENIOWE I PSYCHOLOGICZNE
}

\section{WSTEP}

Według danych Organizacji Narodów Zjednoczonych ds. Wyżywienia i Rolnictwa (ang. Food and Agriculture Organization of the United Nations, FAO) szacuje się, że w 2050 r. globalna populacja będzie wynosiła 9 miliardów ludzi, co ściśle wiąże się ze znaczacym (nawet dwukrotnym) wzrostem zapotrzebowania na żywność w porównaniu do stanu obecnego. W związku $z$ powyższym coraz powszechniej mówi się o konieczności znalezienia alternatywnego sposobu żywienia dla człowieka. Jednym $z$ postulowanych pomysłów jest entomofagia, czyli spożywanie owadów. W społeczeństwach wysoko rozwiniętych nie istnieje ten zwyczaj, co więcej, jest on wręcz tematem tabu, niosacym negatywne odczucia oraz kojarzacym się $z$ prymitywnymi zachowaniami (VAN HUIS i współaut. 2013, KOUŘIMSKÁ i ADÁMKOVÁ 2016). Należy jednak zaznaczyć, że jaja, larwy, poczwarki czy postaci dorosłe niektórych owadów spożywane sa przez ludzi od czasów prehistorycznych. Można to $z$ dużym prawdopodobieństwem potwierdzić, biorac pod uwage następujace fakty: istnienie dowodów archeologicznych w postaci koprolitów, czyli skamieniałych ekskrementów, tradycyjne spożywanie owadów przez wiele grup etnicznych, niskie ryzyko, w porównaniu $z$ polowaniem, oraz dostarczanie przez tkanki owadów podstawowych składników odżywczych (VAN HUIS 2017). Ocenia się, że dla co najmniej 2 miliardów ludzi na świecie owady stanowią część typowej diety, w której wykorzystywanych jest więcej niż 1900 różnych ich gatunków. W odniesieniu globalnym naj- częściej spożywane są owady należace do rzędów: Coleoptera (chrząszcze; 31\%), Lepidoptera (motyle i ćmy; 18\%), Hymenoptera (pszczoły, osy i mrówki; 14\%), Orthoptera (koniki polne, szarańcza i świerszcze; 13\%) oraz Hemiptera (pluskwiaki; 10\%). Odnotowuje się także spożycie termitów (Isoptera; 3\%), ważek (Odonata; 3\%), muchówek (Diptera; 2\%) i innych przedstawicieli gromady owadów (5\%) (VAN HUIS i współaut. 2013, KOUŘIMSKÁ i ADÁMKOVÁ 2016).

W świecie owadów występuja dwa główne typy rozwoju. Na hemimetabolie, czyli rozwój o przeobrażeniu niezupełnym, składaja się następujące etapy metamorfozy: jajo, larwa, nimfa (ostatnie stadium larwalne), postać dorosła (imago). Larwy sa podobne do imago, jednak sa mniejsze, niedojrzałe płciowo i bez rozwiniętych skrzydeł (nimfy posiadaja ich zawiazki). W trakcie kolejnych linień następuje ich wzrost i pojawiaja się struktury morfologiczne charakterystyczne dla imago. Do gatunków hemimetabolicznych zalicza się m.in. przedstawicieli rzędu Orthoptera, Odonata, Hemiptera, Dermaptera (skorki) czy Blattodea (karaczany). Z kolei holometabolia, czyli rozwój o przeobrażeniu zupełnym, to następujące stadia rozwojowe: jajo, larwa, poczwarka i imago. W tym przypadku larwa nie jest podobna do imago, ponadto nie ma rozwiniętych narządów rozrodczych i skrzydeł. Zmiany morfologiczne następuja podczas przepoczwarczania, w wyniku czego powstaje imago. Rozwój holometaboliczny przechodza m.in. Coleoptera, Hymenoptera, Lepidoptera czy Diptera (PIEKARSKA-BonIECKA 2010).

Co ważne, to właśnie typ metamorfozy i etap rozwoju owada warunkuje jego spoży- 
cie, i tak Lepidoptera sa głównie spożywane jako larwy (gasienice), Hymenoptera - w stadium larwalnym i poczwarkowym, Coleoptera - jako larwy i osobniki dorosłe, natomiast reszta $z$ najczęściej spożywanych globalnie owadów jadalnych, głównie po osiagnięciu postaci dorosłej (CERRITOS 2009).

\section{ENTOMOFAGIA - ZASADNOŚĆ ROZWOJU RYNKU}

Produkcja odpowiedniej ilości żywności dla stale rosnacej populacji świata będzie skutkowała dalsza degradacja środowiska. Dla przykładu ocenia się, że rolnictwo pozostaje główną przyczyna antropogennych zmian klimatycznych, w zwiazku $\mathrm{z}$ czym swiat potrzebuje nowych technologii rolniczych i wzorców konsumpcji żywności w oparciu o zdrowsze i bardziej zrównoważone jadłospisy. Żywienie przyszłych populacji bez watpienia wymaga przygotowania odpowiednich alternatyw dla konwencjonalnej konsumpcji. Wśród nich swoje miejsce powinny znaleźć m.in. owady jadalne, grzyby i wodorosty (SACHS 2010).

Według doniesień Europejskiego Urzędu ds. Bezpieczeństwa Żywności (ang. European Food Safety Authority, EFSA) w Europie można hodować m.in. świerszcza domowego (Acheta domesticus, Orthoptera) i bananowego (Gryllodes sigillatus, Orthoptera), szarańczę wędrowna (Locusta migratoria, Orthoptera), macznika mlynarka (Tenebrio molitor, Coleoptera) i olbrzymiego (Zophobas atratus, Coleoptera), pleśniakowca lśniącego (Alphitobius diaperinus, Coleoptera), muchę domowa (Musca domestica, Diptera) i czarna (Hermetia illucens, Diptera) oraz jedwabnika morwowego (Bombyx mori, Lepidoptera), barciaka większego (Galleria mellonella, Lepidoptera) i mniejszego (Achroia grisella, Lepidoptera) (EFSA ScIEnTIFIC CoMmitTeE 2015).

Istnieje kilka powodów, dla których należy rozwijać i promować rynek spożywczy oparty na wykorzystywaniu owadów w codziennej diecie. Po pierwsze, owady stwarzaja stosunkowo niskie ryzyko przenoszenia chorób odzwierzęcych na ludzi, ponadto, należa do odżywczych produktów bogatych w białko, nienasycone kwasy thuszczowe, wapń, żelazo i cynk. Tym samym stanowia racjonalna alternatywe wobec tradycyjnych artykułów spożywczych, m.in. wołowiny czy ryb. Kolejnym bodźcem sa determinanty społeczno-ekonomiczne, zgodnie $z$ którymi mnogość gromady $\mathrm{w}$ przyrodzie oraz niskonakładowa technicznie i kapitałowo (zależnie od pozio$\mathrm{mu}$ inwestycji) hodowla owadów jadalnych pozwala na wprowadzenie ich do jadłospisu w ubogich społeczeństwach. Ostatnim motywem sa czynniki środowiskowe. Hodow- la owadów nie wymaga dużej ilości miejsca [może być prowadzona pod ziemia, np. w przypadku świerszczy Gryllotalpa africana czy Brachytrupes membranaceus (Orthoptera)], jest bardziej ekologiczna w porównaniu $z$ chowem innych zwierzat ze względu na stosunkowo niewielka produkcję gazów cieplarnianych i amoniaku oraz znacznie mniejsze wykorzystanie wody. Ponadto owady moga być karmione odpadami organicznymi (tym samym zmniejszając zanieczyszczenie środowiska i zwiększając wartość odpadów), a w związku $z$ ich morfologia maja bardzo wydajny metabolizm i przekształcanie pokarmu w białko. Dla przykładu świerszcze potrzebuja odpowiednio $12 \mathrm{x}, 4 \mathrm{x}$ i $2 \mathrm{x}$ mniej paszy niż bydło, trzoda chlewna i kury, aby wyprodukować taka sama ilość białka (OONINCX i współaut. 2010, BRITISH ECOLOGICAL SOCIETY 2013, VAN HUIS i współaut. 2013, DEROY i współaut. 2015, AMADI i KIIN-KABARI 2016, TESTA i współaut. 2017).

Pomimo tak wielu zalet, jedna $z$ największych przeszkód jest akceptacja spożycia owadów jadalnych przez człowieka. Jest jednak rzeczą naturalna, że wzorce żywieniowe zmieniaja się szybko. Przykładem moga być owoce morza lub surowe ryby $\mathrm{w}$ formie sushi, które kiedyś nie były powszechnie akceptowane, a obecnie sa przysmakami (RUBY i współaut. 2015).

$\mathrm{Na}$ kwestię spożycia owadów trzeba jednak spojrzeć również od innej strony. Obecnie duża ich część pozyskiwana jest wprost ze środowiska naturalnego (zamieszkuja one przecież różnorodne siedliska, od ekosystemów wodnych i ziemi uprawnej, aż po lasy), co w przypadku ich akceptacji jako codziennego pożywienia miliardów osób, stanowiłoby zagrożenie dla jadalnych gatunków owadów. Tym bardziej rośnie więc znaczenie ich hodowli, zarówno przemysłowej, jak i przydomowej (KoUŘIMSKÁ i ADÁMKOVÁ 2016).

\section{OWADY JAKO POŻYWIENIE}

Wartość odżywcza owadów jadalnych jest bardzo zróżnicowana. Nawet $\mathrm{w}$ obrębie tego samego gatunku może się ona różnić zależnie od stadium rozwoju owada, jego pochodzenia i sposobu żywienia. Wpływa to oczywiście także na ilość makro- i mikroelementów w tkankach. Zawartość lipidów u owadów zależy bowiem od tego, czy gatunki przechodza całkowita, czy też niekompletna metamorfozę. Larwy gatunków holometabolicznych maja zazwyczaj wyższa zawartość tłuszczu, co wynika $z$ wykorzystywania go jako źródło energii podczas metamorfozy. Skutkuje to jednocześnie spadkiem zawartości tłuszczu i wzrostem zawartości białka $\mathrm{u}$ dorosłych owadów. $\mathrm{Z}$ kolei w przypadku 
Tabela 1. Skład odżywczy i wartość energetyczna tkanek wybranych owadów jadalnych.

\begin{tabular}{|c|c|c|c|c|}
\hline $\begin{array}{l}\text { Rząd i gatunek owada } \\
\text { (stadium rozwoju) }\end{array}$ & $\begin{array}{l}\text { Wartość energetycz- } \\
\text { na [kcal/100g s.m.] }\end{array}$ & $\begin{array}{l}\text { Białko } \\
{[\% \text { w s.m.] }}\end{array}$ & $\begin{array}{l}\text { Tłuszcze } \\
{[\% \text { w s.m.] }}\end{array}$ & Odnośnik \\
\hline \multicolumn{5}{|l|}{ Orthoptera } \\
\hline Acheta domesticus (nimfa) & 414,41 & 67,25 & 14,41 & A \\
\hline Acheta domesticus (imago) & 455,19 & 66,56 & 22,08 & A \\
\hline Brachytrupes membranaceus (imago) & $454,7 \pm 2,25$ & $53,4 \pm 0,19$ & $15,8 \pm 0,23$ & $\mathrm{~B}$ \\
\hline Gryllodes sigillatus (imago) & $452 \pm 4,3$ & $70,0 \pm 1,7$ & $18,23 \pm 0,7$ & $\mathrm{C}$ \\
\hline Gryllotalpa africana (imago) & $362,3 \pm 2,34$ & $22,0 \pm 0,86$ & $10,8 \pm 1,24$ & $\mathrm{~B}$ \\
\hline Gryllus assimilis (nimfa) & 546,75 & 59,23 & 34,34 & $\mathrm{D}$ \\
\hline Locusta migratoria (nimfa) & 364,74 & 62,21 & 12,61 & $\mathrm{D}$ \\
\hline Ruspolia differens - brazowe (imago) & $\mathrm{BD}$ & 44,3 & 46,2 & A \\
\hline Ruspolia differens - zielone (imago) & $\mathrm{BD}$ & 43,1 & 48,2 & A \\
\hline Schistocerca gregaria (imago) & $432 \pm 3,9$ & $76,0 \pm 0,9$ & $12,97 \pm 0,7$ & $\mathrm{C}$ \\
\hline Trimerotropis pallidipennis (imago) & $1313^{*}$ & $257^{* *}$ & $38^{* *}$ & $\mathrm{E}$ \\
\hline \multicolumn{5}{|l|}{ Coleoptera } \\
\hline Oxygrylius ruginasus (imago) & $1778^{*}$ & $246^{* *}$ & $113^{* *}$ & $\mathrm{E}$ \\
\hline Rhynchophorus phoenicis (larwa) & 714,3 & 21,1 & 66,6 & $\mathrm{~F}$ \\
\hline Rhynchophorus phoenicis (poczwarka) & $\mathrm{BD}$ & 37,57 & 50,65 & A \\
\hline Rhynchophorus phoenicis (imago) & $\mathrm{BD}$ & 35,57 & 46,69 & A \\
\hline Tenebrio molitor (larwa) & $444 \pm 4,5$ & $52,35 \pm 1,1$ & $24,7 \pm 1,5$ & $\mathrm{C}$ \\
\hline Tenebrio molitor (poczwarka) & 550,0 & 53,1 & 36,7 & A \\
\hline Tenebrio molitor (imago) & 427,9 & 60,2 & 20,8 & A \\
\hline Zophobas morio (larwa) & 582,28 & 54,25 & 40,26 & $\mathrm{D}$ \\
\hline \multicolumn{5}{|l|}{ Lepidoptera } \\
\hline Bombyx mori (larwa) & 389,6 & 53,76 & 8,09 & A \\
\hline Bombyx mori (poczwarka) & 475,04 & 52,62 & 29,36 & $\mathrm{D}$ \\
\hline Galleria mellonella (larwa) & 665,46 & 38,41 & 56,65 & $\mathrm{D}$ \\
\hline Gonimbrasia belina (larwa) & $329,1 \pm 5,21$ & $55,4 \pm 0,22$ & $16,4 \pm 0,36$ & $\mathrm{~B}$ \\
\hline Hyles lineata (imago) & $1957^{*}$ & $254 * *$ & $110^{* *}$ & $\mathrm{E}$ \\
\hline Phasus triangularis & 762,0 & 15,0 & 77,0 & A \\
\hline \multicolumn{5}{|l|}{ Hymenoptera } \\
\hline Apis mellifera (larwa) & 498,63 & 54,38 & 31,24 & $\mathrm{D}$ \\
\hline Apis mellifera (poczwarka) & 476,0 & 49,3 & 20,21 & A \\
\hline Carebara vidua (imago) & $519,8 \pm 6,43$ & $43,6 \pm 0,13$ & $38,2 \pm 0,64$ & B \\
\hline \multicolumn{5}{|l|}{ Diptera } \\
\hline Drosophila melanogaster & $\mathrm{BD}$ & 56,25 & 17,9 & A \\
\hline Musca domestica (larwa) & 552,4 & 63,99 & 24,31 & A \\
\hline Musca domestica (poczwarka) & $\mathrm{BD}$ & 63,1 & 15,5 & A \\
\hline
\end{tabular}

*kcal/kg ż.m.; **g/kg ż.m.; BD - brak danych. Odnośniki: A - RUMPOLD i SCHLÜTER 2013; B - MusundiRE i współaut. 2016; C - ZielińSKA i współaut. 2015; D - BEDNÁŘovÁ i współaut. 2013; E - FinKe 2015; F - WoMENI i współaut. 2012 
gatunków hemimetabolicznych jest odwrotnie - najczęściej większą zawartość lipidów stwierdza się u osobników dorosłych.

Panująca temperatura, wilgotność i nasłonecznienie, czyli środowisko bytowania owada, wywiera wpływ na wartość odżywczą jego tkanek. Otoczenie oddziałuje bowiem na prawidłowy wzrost owada i tempo jego metabolizmu, a w związku $\mathrm{z}$ tym, na zawartość makroelementów tkanek. Co istotne, jest to ściśle zależne od gatunku owada, gdyż każdy $z$ nich posiada specyficzne, optymalne warunki prawidłowego rozwoju.

Skład diety owadów $z$ kolei wpływa na skład chemiczny ich tkanek, podobnie jak w przypadku innych gatunków zwierząt. Zależnie od tego co spożywaja, szczególnie zawartość lipidów i białek może ulegać zmianom. Wynika to $z$ faktu, iż dostarczenie różnych składników pokarmowych pozwala organizmowi na ich odpowiednie wykorzystanie (OONINCX i VAN DER POEL 2011, RUMPOLD i SCHLÜTER 2013, FINKE i OONINCX 2014).

Wartość odżywcza zmienia się także w zależności od sposobu przygotowania potrawy i zastosowanej przed spożyciem obróbki kulinarnej - suszenia, gotowania, smażenia czy pieczenia (VAN HUIS i współaut. 2013).

Ogólnie jednak większość owadów jadalnych, przy odpowiednio zbilansowanym jadłospisie, może zapewnić optymalna ilość energii i białka w diecie człowieka, a także spełnić wymagania aminokwasowe. Tkanki owadów zawierają również jedno- i wielonienasycone kwasy tłuszczowe (BEDNÁŘOVÁ i współaut. 2013). Ponadto, sa bogate w składniki mineralne, m.in. miedź, żelazo, magnez, mangan, fosfor, selen i cynk, a także witaminy, tj. ryboflawine, kwas pantotenowy, biotynę czy kwas foliowy (RUMPOLD i SCHLÜTER 2013).

Ciekawe zestawienie można znaleźć w pracy SRIVASTAVY i współaut. (2009), którzy porównywali wybrane wartości odżywcze owadów jadalnych, ryb i wołowiny. Wynika $z$ niej, że najlepszym źródłem substancji odżywczych spośród badanych przedstawicieli gromady Insecta były gasienice ćmy $z$ gatunku Usata terpsichore (Lepidoptera), które zawierały w $100 \mathrm{~g}$ próbie $370 \mathrm{kcal}$ i 28,2 g białka, przy odpowiednio $219 \mathrm{kcal} \mathrm{i}$ 27,4 g dla chudej wołowiny oraz $170 \mathrm{kcal} \mathrm{i}$ 28,5 g dla gotowanego dorsza. Dalsze analizy wykazały, że tkanki tych gasienic zawierały $35,5 \mathrm{mg}$ żelaza $(\mathrm{Fe}), 3,7 \mathrm{mg}$ tiaminy (wit. $\mathrm{B}_{1}$ ), 1,9 $\mathrm{mg}$ ryboflawiny (wit. $\mathrm{B}_{2}$ ) oraz $5,2 \mathrm{mg}$ niacyny (wit. PP). Dla porównania $\mathrm{w}$ wołowinie stwierdzono odpowiednio 3,5 mg Fe, 0,1 mg wit. $\mathrm{B}_{1}, 0,2 \mathrm{mg}$ wit. $\mathrm{B}_{2}, 6,0$ $\mathrm{mg}$ wit. PP.

\section{WARTOŚĆ ENERGETYCZNA}

Wartość energetyczna owadów jadalnych (Tabela 1) zależy od ich składu, głównie od zawartości lipidów i białek. Analiza tkanek owadów jadalnych występujących w Zimbabwe (Orthoptera: Brachytrupes membranaceus, Gryllotalpa africana, Ornithacris turbida; Lepidoptera: Gonimbrasia belina, Gonanisa maia; Coleoptera: Eulopida mashona; Isoptera: Macrotermes natalensis; Hemiptera: Encosternum delegorguei, Loba leopardina; Hymenoptera: Carebara vidua) wykazała, że ich wartość energetyczna dla różnych gatunków wahała się w zakresie ok. 329-597 kcal/100g suchej masy (MUSUNDIRE i współaut. 2016). Natomiast badanie polskich autorów przyniosło uśrednione, w porównaniu z powyższym, wyniki - energetyczność obserwowanych owadów (Orthoptera: Schistocerca gregaria, Gryllodes sigillatus; Coleoptera: Tenebrio molitor) wynosiła od 432 do $452 \mathrm{kcal} / 100 \mathrm{~g}$ s.m. (ZIELIŃSKA i współaut. 2015). Znacznie wyższą kaloryczność wykazano tymczasem u chrząszczy Rhynchophorus phoenicis (Coleoptera) - 714kcal/100g s.m. (WOMENI i współaut. 2012).

\section{BIAŁKO}

Sama zawartość białka (Tabela 1) nie jest najważniejsza miara, określajaca przydatność dla człowieka. Niezwykle ważna jest bowiem również jego jakość, mierzona tempem strawności białek, czyli ich podatnościa na procesy trawienne, oraz profili aminokwasowych. Jednocześnie należy pamiętać, że skład poszczególnych owadów jadalnych jest bardzo zróżnicowany. Dla przykładu, analiza porównawcza obejmująca dane dla 236 osobników jadalnych wykazała, że zawartość białka w tkankach wahała się w granicach 5,0-77,0\% (RUMPOLD i SCHLÜTER 2013). Wyniki te zdaja się potwierdzać analizy przeprowadzone na 100 gatunkach owadów, u których zawartość białka w suchej masie wynosiła od 13,0 do $77,0 \%$, utrzymując najwyższe przeciętne wartości dla rzędów Odonata (ważek) i Hemiptera (pluskwiaków) (XIAOMInG i współaut. 2010). Ponadto, niejako uśrednione, w odniesieniu do powyższych, wyniki uzyskali badacze z Zimbabwe: zawartość białka w tkankach badanych gatunków owadów mieściła się w przedziale 22,0-55,0\% (MUSUNDIRE i współaut. 2016). Podobnie zreszta jak BEDNÁŘovÁ i współaut. (2013), badający nimfy szarańczy wędrownej, świerszcza kubańskiego (Gryllus assimilis, Orthoptera) i larwy drewnojada (Zophobas morio, Coleoptera), u których stwierdzono od $54,2 \%$ do $62,2 \%$ białka.

$\mathrm{Z}$ kolei w badaniach polskich autorów zawartość białka wahała się od ok. 52,4\% u larw mącznika młynarka, przez ok. 70,0\% 
u dorosłych osobników świerszcza bananowego, do ok. 76,0\% u szarańczy pustynnej (Schistocerca gregaria, Orthoptera). Ponadto, wszystkie testowane owady jadalne zapewniały zadowalajacy poziom niezbędnych aminokwasów, pomimo widocznych w ich składach różnic. Zapotrzebowanie na treoninę, walinę, histydynę i tyrozynę powinno zostać pokryte $\mathrm{w}$ pełni przez wszystkie badane owady. Natomiast żaden $z$ gatunków nie zawierał odpowiednich ilości lizyny. Najwyższe wartości dla izoleucyny, leucyny, tyrozyny, waliny i histydyny uzyskano w S. gregaria, a dla lizyny, metioniny, cysteiny, fenyloalaniny i treoniny $\mathrm{w} G$. sigillatus (ZIELIŃSKA i współaut. 2015).

Strawność białka owadów jadalnych jest bardzo wysoka (80,0-90,0\%), jednak zależna m.in. od gatunku czy sposobu zastosowanej obróbki. W przypadku świeżych termitów Macrotermes subhylanus (Isoptera) wynosiła aż 90,5\%, natomiast trochę niższa stwierdzono dla brazowych i zielonych koników polnych Ruspolia differens (Orthoptera) - odpowiednio 85,7\% i 82,3\% (KINYURU i współaut. 2010). Wyniki te zdaja się potwierdzać analizy Finke (2015), zgodnie z którymi strawność białka koników polnych Trimerotropis pallidipennis (Orthoptera), ciem Hyles lineata (Lepidoptera) i chrzaszczy Oxygrylius ruginasus (Coleoptera) mieściła się w przedziale 86,7-91,2\%.

Porównujac $z$ kolei tradycyjne i niekonwencjonalne źródła białka należy zauważyć, że wieprzowina $(35,2 \%$ w s.m.), soja $(40,4 \%)$ czy krojona sucha wołowina $(45,6 \%)$ maja mniejsza zawartość białka niż larwy jedwabników (54,3\%; Lepidoptera), wędrowna szarańcza azjatycka (58,5\%; Orthoptera), larwy muchy domowej (59,4\%; Diptera), świerszcze (66,7\%; Orthoptera), koniki polne (71,3\%; Orthoptera), cykady (72,0\%; Hemiptera) czy osy (81,0\%; Hymenoptera) (RAN i ZHAO 2014). Natomiast zestawiajac ze soba skład aminokwasów egzogennych (ang. essential amino acids, EAA) u larwy chrząszcza $R$. phoenicis i jaja kurzego stwierdzono, że owady posiadaja większe ilości (mg/g białka) histydyny, izoleucyny i leucyny, tymczasem jaja - treoniny, waliny, metioniny, fenyloalaniny i lizyny. Nie zmienia to jednak faktu, iż różnice w większości przypadków sa nieznaczne, a ogólna zawartość procentowa EAA bardzo zbliżona, aczkolwiek korzystniejsza dla owadów - 45,5\%; jaja - 40,5\%. Pozwala to wnioskować, że larwy chrząszczy sa pożywieniem o dobrym składzie aminokwasowym (WOMENI i współaut. 2012).

\section{TŁUSZCZE}

Zawartość lipidów w tkankach owadów jadalnych (Tabela 1) jest bardzo zróżnico- wana i waha sie w granicach $1,0-77,0 \% \mathrm{w}$ suchej masie. Dla przykładu, u gatunków $z$ rzędu Orthoptera (koniki polne, szarańcza, świerszcze) wynosi średnio $13,0 \%$, natomiast u Coleoptera (chrzaszcze) 33,0\% (RUMPOLD i SCHLÜTER 2013).

Tkanki owadów sa bardzo bogate w cholesterol. Wyniki badania oceniajacego jego zawartość w tłuszczu termitów Macrotermes bellicosus (Ispotera) i gassienic Imbrasia belina (Lepidoptera), które sa powszechnie spożywane w Nigerii, wykazały że średnia zawartość frakcji lipidowej wynosiła 3,6\% (EKOP i współaut. 2010).

Skład kwasów tłuszczowych w owadach jadalnych jest porównywalny ze składem tłuszczu drobiowego i rybiego pod wzgleddem stopnia ich nasycenia, jednak owady charakteryzuja się wyższa zawartością wielonienasyconych kwasów tłuszczowych (RUMPOLD i SCHLÜTER 2013). Wyniki przedstawione przez ZIELIŃSKA i współaut. (2015) wykazały, że ilość nasyconych kwasów tłuszczowych (ang. saturated fatty acids, SFA) jadalnych owadów wahała się od 25,3\% u larw mącznika młynarka do $35,3 \%$ u dorosłych osobników szarańczy pustynnej. Główne SFA to kwas palmitynowy i stearynowy, których największa ilość stwierdzono w dorosłych osobnikach świerszcza bananowego i szarańczy pustynnej (odpowiednio 23,5\% i 7,4\% oraz 23,4\% i 9,3\%). Zawartość jednonienasyconych kwasów tłuszczowych MUFA (ang. monounsaturated fatty acids) wahała się od $34,3 \%$ w $G$. sigillatus, do $43,3 \%$ w $T$. molitor. Najistotniejsze $z$ nich, obecne w tkankach owadow jadalnych, to kwasy oleopalmitynowy i oleinowy. Najwyższa zawartość pierwszego $z$ nich stwierdzono w $G$. sigillatus $(3,8 \%)$, natomiast drugiego w T. molitor (40,9\%). Z kolei udział wielonienasyconych kwasów tłuszczowych PUFA (ang. polyunsaturated fatty acids) wahał się od $26,3 \% \mathrm{w}$ S. gregaria, do $31,4 \%$ w $T$. molitor i $31,9 \%$ $\mathrm{w}$ G. sigillatus. Sa to głównie kwasy linolowy i a-linolenowy. Podobna zawartość (około $30,0 \%$ ) pierwszego $z$ nich wykazano w $G$. sigillatus i $T$. molitor, natomiast najwięcej kwasu a-linolenowego znajdowało się w S. gregaria $(11,4 \%)$ (ZIELIŃSKA i współaut. 2015). Zbliżone wyniki uzyskano w innych badaniach (WOMENI i współaut. 2009, BEDNÁŘOVÁ i współaut. 2013). Najwyższy stosunek kwasów omega-6 do omega-3 wykazano w T. molitor (18:1), natomiast najniższy w S. gregaria (1:1). Najbliższe zalecanym przez Swiatową Organizację Zdrowia (ang. World Health Organisation, WHO) wartości (10:1) znaleziono w G. sigillatus, ok. 14:1 (ZIELIŃSKA i współaut. 2015). Porównywalne wyniki uzyskano również dla świerszcza domowego, ok. 13:1 (TzompA-SosA i współaut. 2014). 


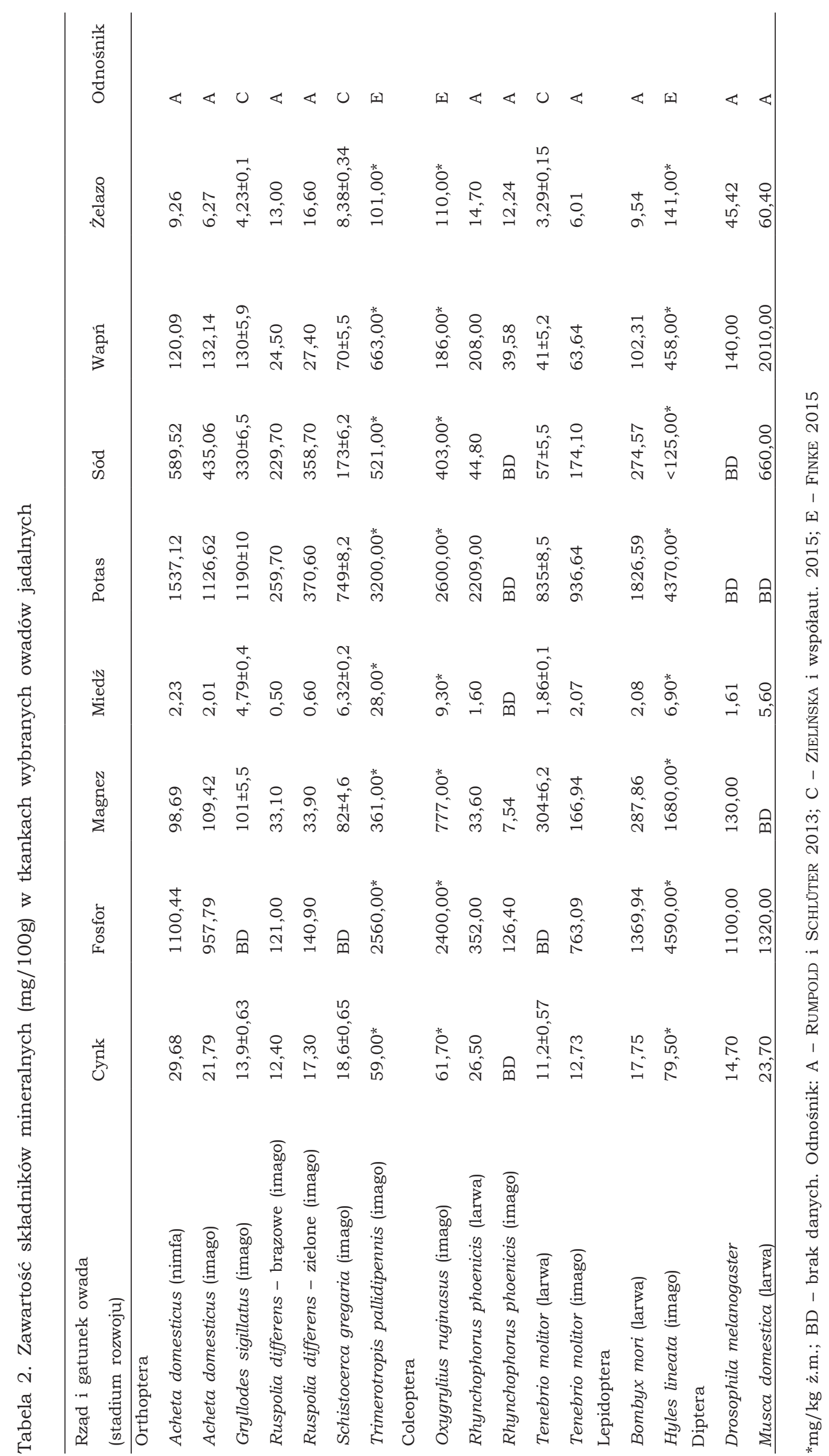




\section{BŁONNIK POKARMOWY}

Owady jadalne charakteryzują się stosunkowo wysoka zawartościa błonnika, występującego w zasadniczej części w postaci chityny, nierozpuszczalnego polisacharydu glukozy zawartego w ich egzoszkielecie. Została ona rozpoznana jako potencjalny alergen (Finke 2007, MuZZARELli 2010, VAN HUIS i współaut. 2013). Zawartość chityny u owadów hodowanych w celach handlowych mieściła się w zakresie 11,6-137,2 mg/kg s.m. (FINKE 2007). Z kolei w badaniach ZIELIŃSKIEJ i współaut. (2015) oceniano ilość błonnika surowego, występującego w świerszczach bananowych, mącznikach młynarkach i szarańczy pustynnej; oscylowała ona w granicach $2,0-3,7 \% \mathrm{w}$ przeliczeniu na sucha masę. W innych analizach zawartość błonnika surowego wahała się pomiędzy $2,0 \%$ a $22,0 \%$ w s.m., zależnie od gatunku owada (MUSUNDIRE i współaut. 2016). Wartości te moga zmieniać się także w zależności od pokarmu pobieranego przez owady (VAN HUIS i współaut. 2013).

\section{SKEADNIKI MINERALNE}

Minerały odgrywają ważną rolę w procesach biologicznych. Ich niedobory, które sa powszechne w wielu krajach rozwijajacych się, moga mieć poważne negatywne konsekwencje dla zdrowia, przyczyniajac się do zaburzeń wzrostu, funkcji układu odpornościowego, czy rozwoju umysłowego i fizycznego (RUMPOLD i SCHLÜTER 2013). Jadalne owady moga być interesujace pod względem zawartości składników mineralnych (Tabela 2), takich jak: żelazo, cynk, potas, sód, wapń, fosfor, magnez, mangan i miedź (VAN HUIS i współaut. 2013). Dla przykładu, dorosłe osobniki szarańczy pustynnej zawierały żelazo oraz miedź i cynk, świerszcze bananowe były bogate w wapń, sód i potas, natomiast larwy macznika młynarka wykazywały wysoka zawartość magnezu (ZIELIŃSKA i współaut. 2015).

Z kolei według analiz FINKE (2015), koniki polne sa dobrym źródłem wapnia, sodu, chloru i miedzi, ćmy - fosforu, magnezu, potasu, żelaza i cynku, tymczasem chrząszcze $O$. ruginasus - manganu.

\section{WITAMINY}

Witaminy sa niezbędne do stymulowania procesów metabolicznych i wzmacniania funkcji układu odpornościowego. Według badaczy owady jadalne sa na ogół bogate w ryboflawinę, kwas pantotenowy i biotynę (Tabela 3). Z drugiej strony, nie sa dobrym źródłem witaminy A, witaminy $\mathrm{C}$, niacyny, a w większości przypadków również tiaminy. W poszczególnych analizach widać jednak dużą zmienność gatunkowa, dotycząca za- wartości witamin. Dla przykładu wyniki opublikowane przez RUMPOLD i SCHLÜTER (2013) prezentuja znaczne wahania zawartości witaminy $\mathrm{E}$ od $<2,2$ do $81 \mathrm{IU} / \mathrm{kg}$ s.m.; dużo wyższe wartości uzyskano jedynie u barciaka większego - 509 IU/kg s.m.. Z kolei według analiz przeprowadzonych przez OONINCXA i DIERENFELDA (2012) zawartość witaminy $\mathrm{E}$ była bardzo niska u większości analizowanych gatunków owadów (9-23,9 IU/ kg s.m.), z wyjątkiem dorosłych osobników Drosophila melanogaster (Diptera) i Microcentrum rhombifolium (Orthoptera). Również zawartość retinolu, jako miara aktywności witaminy A, była niska w większości próbek

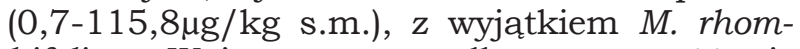
bifolium. W innym przypadku, zawartość witaminy A wahała się $\mathrm{w}$ szerokim przedziale od 0,01 $\mu \mathrm{g} / \mathrm{kg}$ s.m u dorosłego osobnika świerszcza domowego, do $814,5 \mu \mathrm{g} / \mathrm{kg}$ s.m. u konika polnego (Zonocerus variegatus; Orthoptera). Także w analizach prowadzonych przez FINKE (2015) zawartość witamin znacznie różniła się u poszczególnych gatunkach owadów. I tak, koniki polne (Trimerotropis pallidipennis; Orthoptera) zawierały spore ilości witaminy E, chrzaszcze (O. ruginasus; Coleoptera) - witaminy $\mathrm{D}_{3}(13,5 \mu \mathrm{g}$ cholekalcyferolu/kg ż.m.) i witaminy $\mathrm{B}_{12}(23,1 \mu \mathrm{g} /$ kg ż.m.), a ćmy - witaminy C, tiaminy, ryboflawiny, niacyny i biotyny. Podobne zależności można zaobserwować w wynikach badań KINYURU i współaut. (2010). Termity ( $M$. subhylanus) zawierały w składzie największe ilości kwasu askorbinowego, ryboflawiny i retinolu, zielone koniki polne - piroksydyny, kwasu foliowego i niacyny, natomiast brazowe koniki polne - a-tokoferolu.

\section{PRZETWARZANIE}

Analiza właściwości funkcjonalnych ujawniła, że prażenie i grillowanie larw chrząszcza $R$. phoenicis, w przeciwieństwie do gotowania, powodowało niska absorpcję wody. Natomiast oba sposoby obróbki kulinarnej znacznie zwiększały rozpuszczalność białek zawartych w tkankach larw. Co istotne, rozpuszczalność białek była zależna od $\mathrm{pH}$ i najwyższa w zakresie 7-9 (WOMENI i współaut. 2012).

Dodatkowo, w zależności od warunków przetwarzania, obróbka cieplna zmniejszała lub zwiększała strawność białka zawartego w termitach i konikach polnych. Tymczasem wzrost temperatury i czasu trwania ogrzewania przyspieszał rozkład witamin. Dla przykładu, opiekanie termitów w temperaturze $150^{\circ} \mathrm{C}$ przez 5 minut doprowadziło do 34\% zmniejszenia zawartości ryboflawiny, w porównaniu ze świeżymi próbkami. Dalsze suszenie w $30^{\circ} \mathrm{C}$ doprowadziło do znacznie 


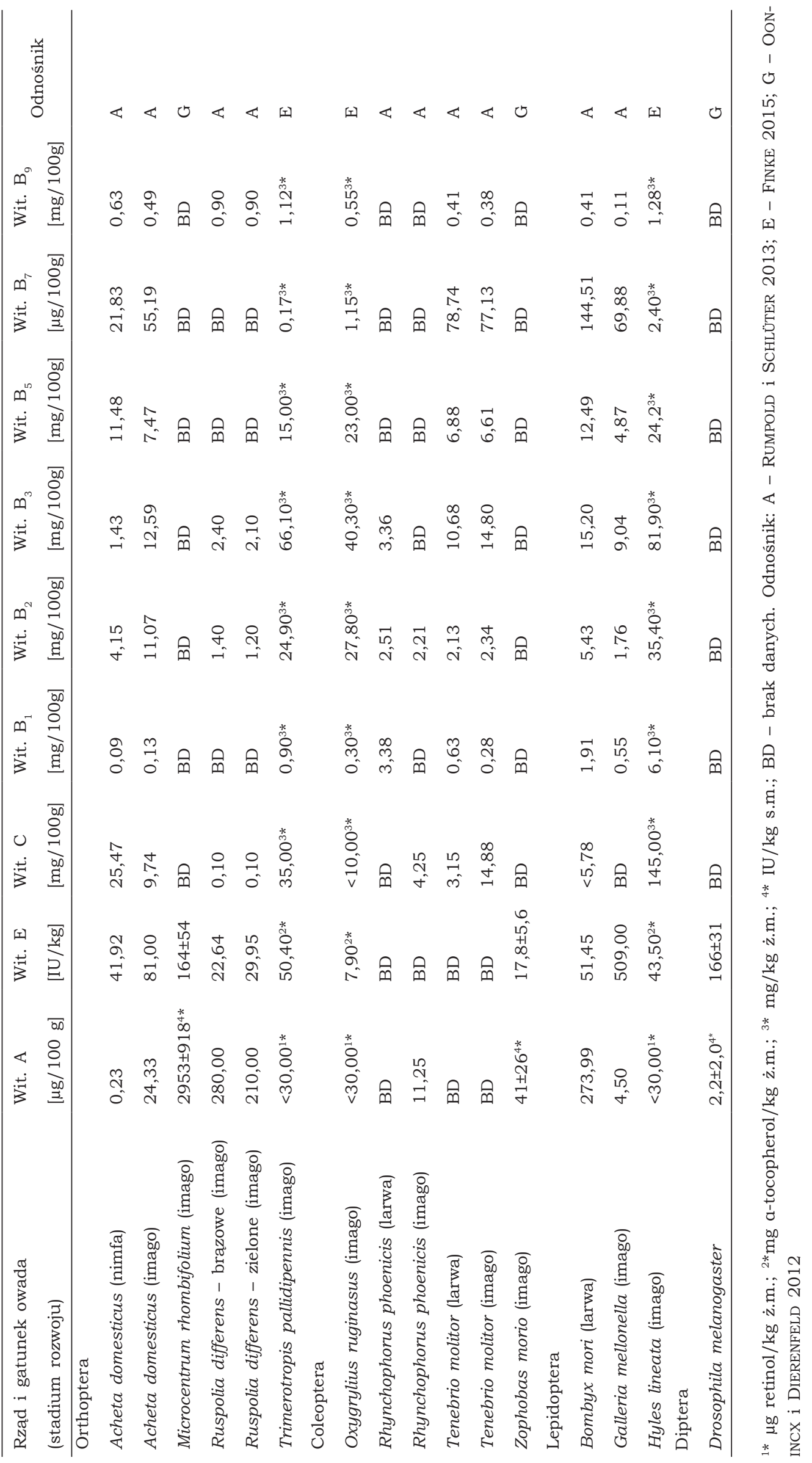


większej utraty (64\%) zawartości ryboflawiny, w porównaniu ze świeżo wysuszoną próbka (46\%). Również suszenie zielonych koników polnych w $150^{\circ} \mathrm{C}$ obniżyło o $63 \%$ zawartość kwasu askorbinowego w tkankach, w porównaniu ze świeża próbką. Tendencja ta była obserwowana dla wszystkich analizowanych witamin w próbkach testowych w podobnych warunkach przetwarzania (KINYURU i współaut. 2010).

\section{SPOŻYWANIE OWADÓW - POTENCJALNE ZAGROŻENIA}

Z badań przeprowadzonych nad bezpieczeństwem spożycia owadów jadalnych wynika, że moga one, podobnie jak żywność konwencjonalna, stanowić potencjalne ryzyko dla zdrowia ludzkiego. Zagrożenia dla zdrowia człowieka, sugerowane i analizowane w literaturze naukowej, dotycza głównie alergenów, zanieczyszczenia mikrobiologicznego i chemicznego, złego wchłaniania i zmian hemodynamicznych (RUMPOLD i SCHLÜTER 2013, TESTA i współaut. 2017). Wśród alergenów można wyróżnić alergeny endogenne, czyli wytwarzane w organizmie, oraz alergeny egzogenne, dostajace się do organizmu z zewnattrz przez wdychanie, połknięcie czy wstrzyknięcie (np. pyłki, kurz, produkty spożywcze, leki).

Owady jadalne, pochodzace zarówno ze środowiska naturalnego, jak i hodowane w gospodarstwach, moga być zakażone drobnoustrojami chorobotwórczymi, w tym bakteriami, wirusami, grzybami czy pierwotniakami. Ponieważ jednak owady sa taksonomicznie dużo bardziej odległe od ludzi niż konwencjonalne zwierzęta gospodarskie uważa się, że ryzyko zoonotycznych infekcji jest niskie. Ryzyko infekcji odzwierzęcych może natomiast wzrosnać w wyniku nieostrożnego stosowania produktów odpadowych czy niehigienicznego obchodzenia się $z$ owadami. Istotne jest zatem zachowanie odpowiednich warunków magazynowania i przygotowywania insektów do spożycia (EILENBERG i współaut. 2015, Finke i współaut. 2015). KLUNDER i współaut. (2012) wskazywali, że zgniecenie larw macznika młynarka powodowało zwiększenie ilości bakterii chorobotwórczych, które mogły się wydostać w wyniku uwolnienia mikroflory jelitowej i zostać rozprowadzone po całej próbce. Ponadto, całkowita eliminację Enterobacteriaceae gwarantowało jedynie gotowanie owadów przez co najmniej $5 \mathrm{mi}-$ nut. Procedurę taka powinno się zastosować również przed dalszym ich przechowywaniem w warunkach chłodniczych.

Wszyscy badacze zgadzaja się, co do ryzyka reakcji alergicznej wziewnej, kontaktowej lub pokarmowej wywołanej stycznościa $z$ antygenami obecnymi w tkankach owadów. Jednak takie ryzyko ogranicza się głównie do grupy osób uczulonych oraz zatrudnionych przy hodowli czy produkcji i nie wydaje się mieć większego znaczenia, szczególnie w porównaniu $z$ powszechniej spożywanymi produktami, tj. skorupiaki czy mięczaki. Drugim elementem jest potrzeba bardziej wszechstronnych badań nad rola substancji antyodżywczych, czyli substancji, ograniczajacych lub uniemożliwiających wykorzystanie składników odżywczych bądź wywierających szkodliwy wpływ na organizm, które często izoluje się $z$ owadów jadalnych (RUMPOLD i SCHLÜTER 2013, EILENBERG i współaut. 2015, FINKE i współaut. 2015). EKOP i współaut. (2010) w badaniu dotyczacym obecności takich substancji w tkankach owadów, wykazali zawartość szczawianów, fitynianów i tanin. Ich stężenie było jednak niższe niż poziom uznawany za szkodliwy dla człowieka. Wpływ substancji antyodżywczych na zdrowie ludzi jest nadal przedmiotem dyskusji, zwłaszcza pod względem potencjalnej kumulacji w organizmie i interakcji ze składnikami odżywczymi (RUMPOLD i SCHLÜTER 2013, VAN HUIS i współaut. 2013, TESTA i współaut. 2017).

\section{PSYCHOLOGICZNE ASPEKTY SPOŻYWANIA OWADÓW}

Neofobia i obrzydzenie (odraza) sa najczęściej wymienianymi zjawiskami, wyjaśniającymi niechęć europejskich konsumentów wobec entomofagii. Neofobia jest tendencja do unikania nieznanego pożywienia, naznaczona w znacznej mierze kultura rodzima, bowiem wobec innych produktów spożywczych niechęć będzie odczuwał np. rdzenny mieszkaniec Finlandii, a wobec innych Japończyk czy Kenijczyk. Warto jednak podkreślić, że prowadzone badania potwierdziły silny negatywny wpływ strachu przed spróbowaniem nowego pożywienia oraz chęci spożywania owadów i/lub potraw stworzonych na ich bazie (HARTMANN i współaut. 2015; VERBEKE 2015; TAN i współaut. 2016a, b;).

Obrzydzenie jest $z$ kolei tradycyjnie rozpatrywane jako podstawowa emocja, która pozostaje uniwersalna dla wszystkich ludzi i chroni ich niejako przed potencjalnym źródłem zagrożenia zdrowia i/lub życia. Należy jednocześnie zauważyć, że odraza jest całkowicie nabyta (ok. 2-5 r.ż.), gdyż małe dzieci wkładaja do ust produkty powszechnie wywołujace wstręt wśród osób starszych. Można więc wnioskować, że obrzydzenie opiera się głównie na wiedzy dotyczącej potencjalnej żywności, a nie na jej właściwościach sensorycznych, czyli cechach ocenianych za pomoca zmysłów: smaku, wzroku, węchu, 
dotyku, słuchu (RUBY i współaut. 2015). Istotnym jest także fakt, że na odczuwanie odrazy wśród poszczególnych osób wpływa wiele czynników, przez co będzie ona zmienna wobec ich wyborów i zachowań oraz silnie naznaczona kulturowo i społecznie (TAN i współaut. 2016a, VERnEAU i współaut. 2016, SOGARI i współaut. 2017). Jest to szczególnie widoczne w przypadku entomofagii, która nie kojarzy się $z$ obrzydzeniem wśród przynajmniej 2 miliardów osób tradycyjnie spożywających owady, podczas gdy takie uczucie wywołuje wśród innych mieszkańców Ziemi (VAN HUIS i współaut. 2013). W tym przypadku myślimy głównie o społeczeństwach zachodnich, które nie maja doświadczenia $z$ owadami jadalnymi, w zwiąku z czym kompulsywnie odrzucaja je jako nieczyste i stwarzajace zagrożenie dla zdrowia (LoOY i współaut. 2014). Takie reakcje obronne znajduja odzwierciedlenie w niskich ocenach gotowości do wprowadzenia owadów, choćby jako substytutu mięsa. $\mathrm{W}$ analizie belgijskiej, ponad $65 \%$ badanych odrzuciło taki pomysł (VERBEKE 2015). Tym ciekawiej przedstawiaja się wyniki jednego $z$ nielicznych badań, które obejmowało analizę odniesienia ludności polskiej względem entomofagii. Wykazały one bowiem neutralna lub wręcz pozytywna postawę konsumentów wobec wykorzystywania owadów jadalnych jako alternatywnego źródła żywności (BARTKOWICZ 2017).

Warto zauważyć, że powyższe czynniki oddziaływać będą w sposób decydujący, ale niejedyny na chęć spożywania owadów. Bowiem na akceptację żywności wpływa wiele czynników, do których zaliczyć należy m.in. potencjalne korzystne efekty zdrowotne, jakość i wartość odżywczą, bezpieczeństwo żywności, a także spodziewany smak i pochodzenie geograficzne (BARRENA i SÁNCHEZ 2013). Analiza prowadzona wśród dwóch skrajnie różnych społeczeństw (niemieckiego i chińskiego) wykazała znaczne rozbieżności dotyczące chęci spożywania owadów jadalnych, a dokładniej poszczególnych ich gatunków. W Niemczech chęć jedzenia owadów była znacznie wyższa w przypadku przetworzonych niż nieprzetworzonych artykułów spożywczych, natomiast w Chinach takiej różnicy nie zaobserwowano. Istotne różnice zauważono także w odniesieniu do wartości odżywczej, smaku, znajomości i akceptacji społecznej entomofagii, $z$ bardziej pozytywnymi postawami zgłaszanymi wśród mieszkańców Chin niż Niemiec. Wyniki wykazały również, że najważniejszym czynnikiem, niezależnym od kraju pochodzenia, był smak (HARTMANN i współaut. 2015). Tymczasem analiza badania prowadzonego w Stanach Zjednoczonych oraz Indiach wskazuje na płeć jako jeden $z$ czynników wpływajacych na potencjalna entomofagię; mężczyźni chętniej niż kobiety (szczególnie w USA) podejmowali próbę spożycia produktów owadopochodnych. Dużo wyższym poparciem charakteryzowało się jedzenie produktów $z$ dodatkiem mąki $z$ owadów, niż całych insektów. Ponadto, najczęstszym powodem odrzucenia możliwości spożycia owadów było obrzydzenie (Amerykanie 57\%, Hindusi 38\%), na dalszych miejscach znalazła się neofobia (odpowiednio 19\% i 17\%) oraz niechęć sensoryczna (12\% i 31\%). Wśród korzyści wynikających ze spożywania insektów obie badane grupy najczęściej wymieniały wartość odżywcza (Amerykanie 66\%, Hindusi 32\%); jednocześnie należy zaznaczyć, że 40\% mieszkańców Indii i 18\% mieszkańców Ameryki nie widziało żadnych korzyści ze spożywania owadów jadalnych (RUBY i współaut. 2015).

Z drugiej strony potencjalne zainteresowanie mieszkańców krajów zachodnich entomofagia wynikać będzie nie $z$ norm społecznych czy braku żywności (jak to często bywa w przypadku zwyczajowego spożywania owadów), lecz $z$ ciekawości i chęci poszukiwania nowych doznań smakowych (BEDNÁŘOVÁ i współaut. 2013, LOOY i współaut. 2014, TAN i współaut. 2016a, BARTKOWICZ 2017, SOGARI i współaut. 2017).

Tak więc, promocja owadów jako źródła pożywienia wyłącznie na podstawie ich zalet odżywczych nie będzie skuteczna strategia dotarcia do przypuszczalnych konsumentów. Zamiast tego musza być oni przekonani o społecznej akceptacji owadów jako żywności, a strategie marketingowe powinny koncentrować się na modelowaniu wizerunku publicznego owadów jadalnych i edukacji dotyczącej smaku poszczególnych produktów pochodzenia owadziego. Przemysł spożywczy powinien koncentrować się na odpowiednio przetworzonej żywności na bazie owadów w znanej kategorii produktu lub profilu smakowym, co powinno zmniejszyć reakcje neofobiczne i zwiększać gotowość do jedzenia takich artykułów (RUBY i współaut. 2015, HARTMANN i SiEgRIST 2017). Przykładem powszechnego wykorzystania zwiazku pochodzenia owadziego jest kwas karminowy (koszenila, E120), pozyskiwany ze zmielonych pancerzyków czerwca kaktusowego (Dactylopius coccus; Hemiptera). Znajduje on zastosowanie w przemyśle spożywczym jako dodatek do żywności o ciemnoczerwonej barwie. Jest barwnikiem wykorzystywanym w produkcji m.in. napojów, jogurtów smakowych, lodów, sosów, galaretek, koncentratów obiadowych czy mrożonych deserów. Można go również znaleźć w niektórych lekach i kosmetykach (KRZYŚKO-ŁUPICKA i współaut. 
2016). Sukces rozpowszechnienia kwasu karminowego wynika $z$ całkowitego przetworzenia produktu (nie występują negatywne skojarzenia, podobnie jak w przypadku mak produkowanych $z$ owadów) oraz braku świadomości konsumentów na temat pochodzenia tego barwnika.

Istotną kwestią wydaje się również odpowiedni wybór odbiorcy. Autorzy w tym przypadku proponują różne podejścia, od kierowania całej uwagi na dzieci i młodzież, które w niedalekiej przyszłości staną się głównymi konsumentami, po rekomendacje zwracajace się ku generacji obecnych konsumentów, którzy moga przekazać nowe wzorce żywieniowe kolejnym pokoleniom. Ważne jest również skupienie uwagi na odpowiednich kwestiach, postuluje się bowiem, żeby zamiast koncentrowania się na zmianie postaw osób, które obecnie odrzucaja ideę spożywania owadów, badać czynniki wpływające na jej akceptację wśród ludzi skłonnych do entomofagii, gdyż to oni sa potencjalnymi konsumentami (House 2016, PAYNE i współaut. 2016).

\section{PODSUMOWANIE}

Badania dowodza, że entomofagia jest ciekawa i potrzebna alternatywa dla żywności uznawanej za konwencjonalna, szczególnie istotna $z$ powodu stale zwiększającej się liczby mieszkańców świata. Owady jadalne, zależnie od wielu czynników, mogą być dobrym źródłem energii, białek, tłuszczów, błonnika pokarmowego oraz witamin i minerałów. Dla przykładu, dorosły człowiek o dobowym zapotrzebowaniu energetycznym 2000 kcal, aby pokryć niezbędna ilość białka (75 g, przyjmujacc 15\% pokrycia dziennego zapotrzebowania $z$ białka) musiałby spożyć 291,8 g imago konika polnego lub 295,3 g chrzaszcza O. ruginasus lub 304,9 g ćmy. Natomiast dla pokrycia $100 \%$ zapotrzebowania na tłuszcze, odpowiednio 1763,2 g, $663,7 \mathrm{~g}$ i $681,8 \mathrm{~g}$. Oczywiście wszystko to przy założeniu, że nie spożywa innych źródeł białka i tłuszczu.

Naturalnie, istnieją również negatywne aspekty ich spożywania, wśród których można wymienić potencjalną alergenność, zanieczyszczenie mikrobiologiczne czy zawartość substancji antyodżywczych. Dla wszystkich z nich istnieje potrzeba prowadzenia dalszych badań, które pozwola na wyjaśnienie istniejacych wątpliwości i ujednolicenie stanowiska ekspertów. Jednak największa bariera, która powstrzymuje społeczeństwa zachodnie przed spożywaniem owadów, pozostaje psychika ludzka. $Z$ jednej strony, odczuwa się strach przed nowym (neofobia) i odrazę wobec „prymitywnego jedzenia”, $z$ drugiej na- tomiast, ciekawość wobec nieszablonowych produktów i smaków. Właśnie dzięki temu ludzie sa w stanie otwierać się na nowości, również kulinarne, i $z$ czasem wprowadzać je do codziennych jadłospisów.

$$
\text { Streszczenie }
$$

Szacuje się, że w 2050 r. globalna populacja będzie wynosiła 9 miliardów ludzi, co skutkować będzie znaczącym wzrostem zapotrzebowania na żywność, w porównaniu do stanu obecnego. Coraz powszechniej dyskutuje się więc nad koniecznościa znalezienia alternatywnego sposobu żywienia dla człowieka. Jednym z postulowanych pomysłów jest entomofagia, czyli spożywanie owadów. Jest to idea dobra $z$ perspektywy zdrowotnej, środowiskowej i społeczno-demograficznej. W aspekcie żywieniowym większość owadów jadalnych, przy odpowiednio zbilansowanym jadłospisie, może zapewnić optymalną ilość energii i białka w diecie człowieka, a także spełnić wymagania aminokwasowe. Tkanki owadów charakteryzuja się również wysoką zawartością jedno- i wielonienasyconych kwasów tłuszczowych oraz sa bogate $\mathrm{w}$ składniki mineralne i witaminy. Koncepcja ta napotyka jednak wiele przeszkód, wiążących się głównie $z$ aspektami psychologicznymi. W celu wyjaśnienia niechęci europejskich konsumentów wobec entomofagii najczęściej wymienia się zjawiska neofobii i obrzydzenia. Jednocześnie mieszkańców państw zachodnich charakteryzuje ciekawość kulinarna i stałe poszukiwanie nowych doznań smakowych, być może zainteresują się więc entomofagia.

\section{LITERATURA}

AMADI E. N., KIIN-KABARI D. B., 2016. Nutritional composition and microbiology of some edible insects commonly eaten in Africa, hurdles and future prospects: A critical review. J. Food Microbiol. Safety Hygiene 1, 107.

BARRENA R., SÁNCHEZ M., 2013. Neophobia, personal consumer values and novel food acceptance. Food Qual. Prefer. 27, 72-84.

BARTKOWICZ J., 2017. Tri-city consumers attitudes towards eating edible insect as an alternative source of food. Handel Wewnętrzny 1, 156166.

BednÁŘová M., Borkovcová M., MlČeK J., RoP O., ZEMAN L., 2013. Edible insects - species suitable for entomophagy under condition of Czech Republic. Acta Univ. Agricult. Silvicult. Mendelianae Brunensis 61, 587-593.

BRITISH ECOLOGICAL SOCIETY, 2013. Entomophagy: feeding the nine billion world population in 2050. BES, London. http://tinyurl.com/ybbklrnu.

CERRITOS R., 2009. Insects as food: an ecological, social and economical approach. CAB Rev. Persp. Agricult. Veterinary Sci. Nutrit. Nat. Resources 4, 1-10.

Deroy O., ReAdE B., Spence C., 2015. The insectivore's dilemma, and how to take the West out of it. Food Qual. Prefer. 44, 44-55.

EFSA SCIENTIFIC COMMITTEe, 2015. Risk profile related to production and consumption of insects as food and feed. EFSA J. 13, 4257.

EILENBERG J., VlaK J. M., NiELSEN-Leroux C., CAPPEllozza S., Jensen A. B., 2015. Diseases in insects produced for food and feed. J. Insects Food Feed 1, 87-102.

EKoP E. A., UDOH A. I., AKPAN P. E., 2010. Proximate and anti-nutrient composition of four edi- 
ble insects in Akwa Ibom State, Nigeria. World J. Appl. Sci. Technol. 2, 224-231.

FinKE M. D., 2007. Estimate of chitin in raw whole insects. Zoo Biol. 26, 105-115.

FINKE M. D., 2015. Complete nutrient content of three species of wild caught insects, pallid-winged grasshopper, rhinoceros beetles and white-lined sphinx moth. J. Insects Food Feed 1, 281-292.

Finke M. D., OONINCX D. D., 2014. Insects as food for insectivores. [W:] Mass Production of Beneficial Organisms: Invertebrates and Entomopathogens. MORALES-RAMOS J., ROJAS G., SHAPIRO-ILAN D. I. (red.). Elsevier, New York, 583-616.

Finke M. D., Rojo S., Roos N., Van Huis A., YEN A. L., 2015. The European Food Safety Authority scientific opinion on a risk profile related to production and consumption of insects as food and feed. J. Insects Food Feed 1, 245-247.

HARTMANN C., SiEgRIST M., 2017. Insects as food: perception and acceptance. Findings from current research. Ernahrungs Umschau 64, 4450.

HaRTMANN C., SHI J., GIUSTO A., Siegrist M., 2015. The psychology of eating insects: A cross-cultural comparison between Germany and China. Food Qual. Prefer. 44, 148-156.

House J., 2016. Consumer acceptance of insect-based foods in the Netherlands: Academic and commercial implications. Appetite 107, 47-58.

KinyURU J. N., Kenji G. M., NJOROGe S. M., AYIEKO M., 2010. Effect of processing methods on the in vitro protein digestibility and vitamin content of edible winged termite (Macrotermes subhylanus) and grasshopper (Ruspolia differens). Food Bioproc. Technol. 3, 778-782.

KLUNDER H. C., WOLKERS-ROOIJACKERS J., KORPELA J. M., NOUT M. J., 2012. Microbiological aspects of processing and storage of edible insects. Food Control 26, 628-631.

KOUŘIMSKÁ L., ADÁMKOVÁ A., 2016. Nutritional and sensory quality of edible insects. NFS J. 4, 22-26.

KRZYŚKO-ŁUPICKA T., KRECIDŁO M., KRĘCIDŁO Ł., 2016. Barwniki $w$ żywności a zdrowie konsumentów. Kosmos. Probl. Nauk Biol. 65, 543552.

LoOY H., Dunkel F. V., WoOD J. R., 2014. How then shall we eat? 'Insect-eating attitudes and sustainable foodways. Agricult. Human Val. $31,131-141$.

MusundiRe R., ZVIDZAI C. J., Chidewe C., Samende B. K., Chemura A., 2016. Habitats and nutritional composition of selected edible insects in Zimbabwe. J. Insects Food Feed 2, 189-198.

MuZzARELl R. A., 2010. Chitins and chitosans as immunoadjuvants and non-allergenic drug carriers. Marine Drugs 8, 292-312.

OONINCX D. G., VAN DER POEL A. F., 2011. Effects of diet on the chemical composition of migratory locusts (Locusta migratoria). Zoo Biol. 30, 9-16.

OONINCX D. G., DieRENFELD E. S., 2012. An investigation into the chemical composition of alternative invertebrate prey. Zoo Biol. 31, 4054.

OonincX D. G., VAN ItTERBEeCK J., HeEtKamp M. J., VAN DEN BRAND H., VAN LOON J., VAN HUIS A., 2010. An exploration on greenhouse gas and ammonia production by insect species suitable for animal or human consumption. Plos One 5, e14445.
Payne C. L., Dobermann D., Forkes A., House J., Josephs J., McBride A., MÜller A., QUILLIAM R. S., SOARES S., 2016. Insects as food and feed: European perspectives on recent research and future priorities. J. Insects Food Feed 2, 269-276.

PIEKARSKA-BONIECKA H., 2010. Rozwój owadów [W:] Entomologia. Część 1 - entomologia ogólna. WilKANIEC B. (red.). Państwowe Wydawnictwo Rolnicze i Leśne, Warszawa, 137-160.

RAN W., ZHAO C., 2014. Research Progress on the Development and Utilization of Proteins in Edible Insects. Agricult. Sci. Technol. 15, 683687.

Ruby M. B., Rozin P., CHAN C., 2015. Determinants of willingness to eat insects in the USA and India. J. Insects Food Feed 1, 215225.

RUMPOLD B. A., SCHLÜTER O. K., 2013. Nutritional composition and safety aspects of edible insects. Mol. Nutrit. Food Res. 57, 802-823.

SACHS J., 2010. Rethinking macroeconomics: knitting together global society. Broker 18, 1-3.

SOGARI G., MENOZZI D., MORA C., 2017. Exploring young foodies $\square$ knowledge and attitude regarding entomophagy: A qualitative study in Italy. Int. J. Gastr. Food Sci. 7, 16-19.

SRIVASTAVA S. K., BABU N., PANDEY H., 2009. Traditional insect bioprospecting - As human food and medicine. Indian J. Tradit. Knowl. 8, 485-494.

TAN H. S., Fischer A. R., Van TriJP H. C., STIEGER M., 2016a. Tasty but nasty? Exploring the role of sensory-liking and food appropriateness in the willingness to eat unusual novel foods like insects. Food Qual. Prefer. 48, 293-302.

TAN H. S., VAN DEN Berg E., STIEGER M., 2016b. The influence of product preparation, familiarity and individual traits on the consumer acceptance of insects as food. Food Qual. Prefer. 52, 222-231.

Testa M., Stillo M., Maffei G., Andriolo V., GARDOIS P., ZOTTI C. M., 2017. Ugly but tasty: A systematic review of possible human and animal health risks related to entomophagy. Crit. Rev. Food Sci. Nutrit. 57, 37473759.

Tzompa-Sosa D. A., Yi L., Van Valenberg H. J. F., Van Boekel M. A. J. S., LaKemond C. M. M., 2014. Insect lipid profile: aqueous versus organic solvent-based extraction methods. Food Res. Int. 62, 1087-1094.

VAN HUIS A., 2017. Did early humans consume insects? J. Insects Food Feed 3, 161-163.

VAN HUIS A., VAN ITTERBEECK J., KLUNDER H., Mertens E., Halloran A., Muir G., Vantomme P., 2013. Edible insects. Future prospects for food and feed security. FAO, Rome. http:// www.fao.org/docrep/018/i3253e/i3253e.pdf.

VERBEKE W., 2015. Profiling consumers who are ready to adopt insects as a meat substitute in a Western society. Food Qual. Prefer. 39, 147-155.

Verneau F., la Barbera F., Kolle S., Amato M., DEL GiUdice T., GRUnerT K. G., 2016. The effect of communication and implicit associations on consuming insects: An

experiment in Denmark and Italy. Appetite 106, 30-36.

Womeni H. M., Linder M., Tiencheu B., MBiAPo F. T., Villeneuve P., FAnNi J., PARMEnTIER M., 2009. Oils of insects and larvae consumed in Africa: potential sources of polyunsaturated fatty acids. Oilseeds Fats Crops Lipids 16, 230-235. 
Womeni H. M., TIEncheU B., LINDER M., NABAYO E. M., Tenyang N., MBiapo F. T., Villeneuve P., FANNI J., PARMENTIER M., 2012. Nutritional value and effect of cooking, drying and storage process on some functional properties of Rhynchophorus phoenicis. Int. J. Life Sci. Pharma Res. 2, 203-219.

XiaOming C., Ying F., Hong Z., ZhiYong C., 2010. Review of the nutritive value of edible insects.
[W:] Forest insects as food: humans bite back, proceedings of a workshop on Asia-Pacific resources and their potential for development. DURST P. B., JOHNSON D. V., LESLIE R. L., SHONO K. (red.). FAO, Bangkok, 85-92.

ZIELIŃSKA E., BARANIAK B., KARAŚ M., RYBCZYŃSKA K., JAKUBCZYK A., 2015. Selected species of edible insects as a source of nutrient composition. Food Res. Int. 77, 460-466.

KOSMOS Vol. 68, 3, 489-501, 2019

\author{
NicOLA SZEJA
}

Department of Hematology and Cancer Prevention, School of Public Health in Bytom, Medical University of Silesia in Katowice, 18 Piekarska Str., 41-902 Bytom, E-mail: nicola.szeja@med.sum.edu.pl

\title{
ENTOMOPHAGY - NUTRITIONAL AND PSYCHOLOGICAL ASPECTS
}

\section{Summary}

It is estimated that in 2050, the global population will be 9 billion people, which will result in a significant increase in the demand for food compared to the current state. In connection with the above, the need to find an alternative way of feeding for human beings is increasingly discussed. One of the postulated ideas is entomophagy, or eating insects. This is a good idea from a health, environmental and socio-demographic perspective. In terms of nutrition, the majority of edible insects, with a properly balanced menu, can provide the optimal amount of energy and protein in the human diet, as well as meet the requirements of amino acids. Insect tissues are also characterized by high content of mono- and polyunsaturated fatty acids and are rich in minerals and vitamins. This concept, however, faces many obstacles, mainly relating to psychological aspects. In order to explain the reluctance of European consumers towards entomophagy, the most common are the phenomena of neophobia and disgust. At the same time, the inhabitants of Western countries are characterized by culinary curiosity and constant search for new taste sensations, which is undeniably associated with entomophagy.

Key words: diet alternative, edible insects, nutritional values, psychological aspects, source of food 